\title{
Pemberdayaan Zakat : Model Intervensi Kemiskinan Dengan Microfinance Syariah Berbasis Masyarakat DPU DT Jawa Barat, Indonesia
}

\author{
Asep Suryanto \\ Universitas Siliwangi \\ asepsuryanto@unsil.ac.id
}

\begin{abstract}
This study aims to find out about the general description of the empowerment of zakat conducted by DPU Daarut Taubiid in intervening poverty, through community basedIslamic microfinance. This research is a qualitative research using grounded research method that moves from empirical level to conceptual-theoretical level. The results showed that the empowerment of zakat by DPU Daarut Taubiid through misykat program in the form of financing micro business capital for small groups-based zakah mustahik by adapting the Islamic microfinance model equipped with multifunctional facilitation.
\end{abstract}

Keywords : Poverty, Zakat Empowerment, Islamic Microfinance

\begin{abstract}
Abstrak
Penelitian ini bertujuan untuk mengetahui tentang gambaran umum tentang pemberdayaan zakat yang dilakukan oleh DPU Daarut Tauhiid dalam mengintervensi kemiskinan, melalui kegiatan microfinance syariah berbasis masyarakat. Penelitian ini merupakan penelitian kualitatif dengan menggunakan metode penelitian grouded yakni bergerak dari level empirikal menuju ke level konseptual-teoritikal. Hasil penelitian menunjukkan bahwa pemberdayaan zakat yang dilakukan DPU Daarut Taubiid melalui program misykat adalah pembiayaan modal usaha mikro berbasis kelompok mustabik zakat dengan mengadaptasi model keuangan mikro Islam yang dilengkapi dengan kegiatan pedampingan yang multifingsi.
\end{abstract}

Kata Kunci : kemiskinan, pemberdayaan zakat, kuangan mikro Islam

Permalink/DOI: http://dx.doi.org/10.18326/infsl3v12i1.85-106 


\section{Pendahuluan}

Persoalan kemiskinan sebenarnya bukan hanya sekedar jumlah dan persentase saja, akan tetapi juga menyangkut tingkat kedalaman dan keparahan kemiskinan. Oleh karena itu, kebijakan pemerintah disamping harus mampu memperkecil jumlah penduduk miskin, juga harus dapat menurunkan tingkat kedalaman dan tingkat keparahan kemiskinan. Berdasarkan data BPS bulan September 2017, jumlah penduduk miskin di seluruh wilayah Indonesia baik di desa maupun di kota sebanyak 10,12\% dari jumlah penduduk atau sebanyak 26,58 juta orang. Persentase penduduk miskin di pedesaan $(13,47 \%)$ lebih besar dari persentase penduduk miskin diperkotaan $(7,26 \%)$.

Terdapat beberapa faktor yang menjadi sebab kemiskinan di Indonesia, misalnya karena persoalan sumber daya insani yang kurang, persoalan infrastruktur dan ekonomi. Jika dilihat dari dimensi ekonomi, penyebab kemiskinan dapat berupa kurangnya diversifikasi keahlian dari penduduk miskin, tidak memiliki modal untuk usaha, buruknya infrastruktur sehingga menyebabkan arus barang tidak lancar, atau karena kurangnya kemampuan kewirausahaan masyarakat. Disamping itu sebagian masyarakat Indonesia ada yang tidak berpenghasilan karena kurangnya lapangan pekerjaan yang tersedia. Bahkan masyarakat Indonesia yang statusnya sebagai pekerja pun masih terhitung sebagai masyarakat miskin.

Sebenarnya terdapat beberapa cara dalam mengentaskan kemiskinan di Indonesia diantaranya, yaitu 1) membuka akses pendidikan seluas-luasnya baik formal maupun informal hingga pelatihan berwirausaha bagi masyarakat; 2) memberikan fasilitas kesehatan gratis atau murah; 3) ada kemudahan akses untuk memulai usaha melalui pemberian permodalan dan birokrasi pengurusan administrasi usaha. Sehinga tidak semua masyarakat diarahkan untuk menjadi pekerja, tetapi didorong untuk menjadi entrepreneur.

Islam dalam mengatasi permasalahan kemiskinan sejak awal telah membuat aturan baku bahkan menjadi core-nya ekonomi Islam, yaitu perintah untuk mengeluarkan zakat bagi para muzaki 
dan menyalurkannya kepada 8 kelompok mustahik yang dua diantaranya adalah kaum miskin dan fakir. Islam memberikan solusi pengentasan kemiskinan melalui konsep zakat, hal ini sebagaimana disebutkan dalam al Qur'an surat at Taubah ayat 60,

"Sesungguhnya zakat-zakat itu, hanyalah untuk orang-orang fakir, orang-orang miskin, pengurus-pengurus zakat, para mu'allaf yang dibujuk hatinya, untuk (memerdekakan) budak, orang-orang yang berhutang, untuk jalan Allah dan untuk mereka yang sedang dalam perjalanan, sebagai suatu ketetapan yang diwajibkan Allah, dan Allah Maha Mengetahui lagi Maha Bijaksana".

Dalam Islam, (Irfan Syauqi Beik, 2015) zakat merupakan instrumen yang bertugas menciptakan keadilan distribusi, pemerataan pembangunan, dan sekaligus menjadi alat pemberdayaan sosial ekonomi kelompok miskin serta kelompok termarjinalkan.

Selama ini dana ZIS di Indonesia dikelola oleh BAZNAS dan LAZ yang pengelolaanya diatur dalam undang-undang pengelolaan zakat no. 23 tahun 2011, dimana pasal 3 menyebutkan bahwa pengelolaan zakat memiliki tujuan: 1) meningkatkan efektivitas dan efisiensi pelayanan dalam pengelolaan zakat; 2) meningkatkan manfaat zakat untuk mewujudkan kesejahteraan masyarakat dan penanggulangan kemiskinan. Adapun lembaga pengelolanya adalah BAZNAS yang berwenang melakukan pengelolaan zakat secara nasional, dan LAZ yang dibentuk masyarakat untuk membantu BAZNAS dalam pelaksanaan pengumpulan, pendistribusian, dan pendayagunaan zakat. Oleh karena itu, masyarakat khususnya kaum muslimin ikut berperan serta dalam program pengentasan kemiskinan sebagai bentuk kepedulian sosial melalui lembagalembaga tertentu yang dibuat oleh masyarakat. Hal ini ditandai dengan tumbuhnya Lembaga Amil Zakat Nasional (LAZNAS) yang lahir dari masyarakat, disamping Badan Amil Zakat Nasional (BAZNAS) yang dibentuk oleh pemerintah.

Zakat yang diimplementasikan saat ini tidak memainkan peran yang sangat penting dalam kehidupan sosial ekonomi umat Islam, karena peran zakat hanya sebatas aspek amalnya saja daripada aspek sosio-ekonominya (Ahmad F. Oran, 2009 : 143-153). Pendayagunaan 
dana zakat selama ini masih menganut paradigma lama, yaitu dana zakat harus dibagi habis untuk semua golongan yang ditentukan dan untuk konsumsi sesaat sehingga pendayagunaan zakat untuk tujuan pemberdayaan ekonomi produktif belum menjadi prioritas utama. Pendistribusi ZIS masih belum efektif dan kemanfaatan dana ZIS melalui pemberdayaan ekonomi tergolong masih kurang efisien (Nedi Hendri dan Suyanto, 2015:63-73). Di samping itu, masih lemahnya infrastruktur dan skill tenaga pendamping program pemberdayaan dana zakat menjadi faktor kendala tersendiri bagi sebagian LAZ dan BAZ. Oleh karena itu, diperlukan pembaharuan pendayagunaan zakat yang menyangkut aspek pemanfaatan dana zakat secara produktif dan dilakukan secara profesional.

Munculnya lembaga-lembaga amil zakat menampilkan sebuah harapan akan tertolongnya kesulitan hidup kaum dhuafa. Masalah kemiskinan dan pengangguran yang terjadi di Indonesia akan terselesaikan. Akan tetapi harapan ini akan sulit tercapai jika lembaga amil zakat tidak memiliki orientasi dalam pemanfaatan dana zakat yang tersedia (Ramadhita, 2013:24-34).

DPU DT (Dompet Peduli Umat Daarut Tauhiid) merupakan salah satu LAZNAS (Lembaga Amil Zakat Nasional) yang ikut berperan aktif dalam upaya menanggulangi kemiskinan melalui pendayagunaan zakat untuk pemberdayaan ekonomi masyarakat. Kiprah DPU DT ini dimulai pada tahun 1999 yang berpusat di Kota Bandung, sampai sekarang sudah memiliki 9 cabang yang tersebar di Jakarta, Bogor, Batam, Garut, Tasikmalaya, Semarang, Yogyakarta, Lampung dan Palembang.

DPU DT yang berpusat di Bandung sampai pertengahan 2016 omzetnya sudah mencapai Rp. 1 Milyar lebih. Adapun pendayagunaan dana tersebut salah satunya disalurkan melalui program misykat, yaitu mickrofinance berbasis pemberdayaan masyarakat dengan jumlah anggota di Provinsi Jawa Barat sebanyak 2.401 rumah tangga.

Berdasarkan uraian latar belakang penelitian tersebut, maka masalah penelitian ini dapat dirumuskan sebagai berikut : Bagaimana model pemberdayaan zakat yang dilakukan oleh DPU DT? 


\section{Pemberdayaan Zakat}

Menurut Hamka (2013) zakat sebagai bagian dari ajaran agama Islam menjadi dasar dan pendorong umat Islam untuk berpartisipasi dan berkontribusi dalam program dan pengembangan masyarakat. Oleh karena itu, pemberdayaan zakat harus dilakukan dengan pengelolaan program dan kegiatan pengembangan masyarakat sehingga dapat memenuhi kebutuhan praktis maupun kebutuhan strategis.

Zakat memiliki fungsi yang sangat strategis baik dalam konteks sosial maupun konteks ekonomi, yaitu menggerakkan perekonomian umat Islam. Zakat sebagai sistem jamnian sosial akan bermanfaat bagi penanggulangan kemiskinan, karena dalam Islam setiap individu harus layak hidup di tengah masyarakat manusia, yakni dengan terpenuhinya kebutuhan pokok mereka baik berupa sandang, pangan, dan papan serta terpenuhi kebutuhan akan pekerjaannya. Dalam buku yang berjudul Pemberdayan Zakat, Membangun Perspektif Pengelolaan Zakat Nasional, Direktorat Pemberdayan Zakat kementerian Agama RI menyebutkan bahwa zakat memiliki pengaruh yang sangat positif dalam mendorong gerak roda perekonomian umat Islam (Tim Penyusun Direktorat Pemberdayan Zakat, 2013: 18). Pada satu sisi distribusi zakat baik secara konsumtif maupun produktif akan dapat mengentaskan kemiskinan dan pada sisi yang lain dapat menghindari penumpukan harta di tangan orang-orang kaya saja. Hal ini sebagaimana di kemukakan dalam al Qur'an surat al hasyr (59) ayat 7.

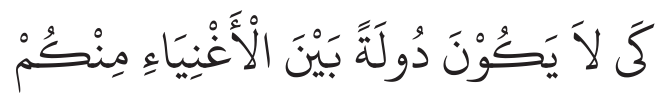

... "supaya harta itu jangan beredar di antara orang-orang kaya saja di antara kamu. “...

Pemberdayaan zakat perlu dilakukan melalui program pemanfaatan dana zakat untuk mendorong mustahik agar mampu memiliki usaha secara mandiri. Hal ini dapat diwujudkan dalam bentuk pengembangan modal usaha mikro bagi yang sudah berjalan atau perintisan usaha mikro yang baru. Dimana proses 
pendayagunaan zakat tersebut harus dilakukan melalui tahapan yang sesuai dengan ketentuan perundang-undangan. Dengan pemberdayaan zakat tersebut diharapkan memiliki dampak yang positif bagi mustahik baik secara ekonomi, sosial, maupun spiritual. Lebih lanjut Khaliq menyebutkan bahwa model pemberdayaan zakat tersebut harus disinergikan dengan program pengentasan kemiskinan yang dilakukan oleh pemerintah (Kholiq, 2012:39-47).

\section{Fungsi Sosial-Ekonomi Zakat}

Redistribusi pendapatan dan kekayaan dalam Islam dilakukan melalui institusi zakat dengan tujuan untuk alat pengentasan kemiskinan juga sebagai mekanisme stabilisasi dengan memperbaiki taraf kehidupan kaum fakir dan miskin, hal ini sebagai implementasi dari semangat kerjasama dan saling tolong menolong dengan berbagi kekayaan sehingga dapat mengurangi ketidaksetaraan ekonomi dan memperbaiki status sosio-ekonomi penerima manfaat zakat secara keseluruhan (Ahmad, 1984:3-18).

Zakat memiliki penggunaan tertentu menurut ketentuan yang telah diatur dalam syariah Islam. Dimana zakat diperkenalkan mencakup semua segi kehidupan baik material maupun spiritual, seperti jaminan akhlak, pendidikan, jaminan politik, jaminan pertahanan, jaminan pidana, jaminan ekonomi, kemanusiaan, jaminan kebudayaan, dan jaminan sosial (Qardawi, 2007:878). Suprayitno (2017:61-69) zakat dimaksudkan untuk merangsang pembagunan ekonomi, pendidikan, sosial, pemberdayaan sumber daya manusia, kesehatan, agama, dan program asuransi.

Secara ekonomi, menurut Barizah Abu Bakar (2007: 25-40) zakat memiliki efek multiplier pada pekerjaan dan pendapatan karena sejumlah dana zakat yang diinvestasikan yang sesuai dengan prioritas produksi secara keseluruhan dalam sebuah sistem ekonomi akan menguntungkan kaum miskin pada khususnya, yakni berupa kesempatan kerja yang terbuka lebar dan peningkatan pendapatan ekonomi masyarakat sehingga berefek pada meningkatnya taraf hidup masyarakat yang pada akhirnya akan meningkatkan volume agregat koleksi zakat dan pertumbuhan ekonomi. 
Dalam konteks keuangan publik, Norazlina Abd. Wahab dan Abdul Rahim Abdul Rahman (2011: 43-62) menyatakan bahwa zakat diyakini sebagai salah satu instrumen keuangan publik untuk mencapai keadilan sosial-ekonomi masyarakat. Adapun mekanisme keadilan sosial-ekonomi dengan instrument zakat dapat digambarkan sebagai berikut:

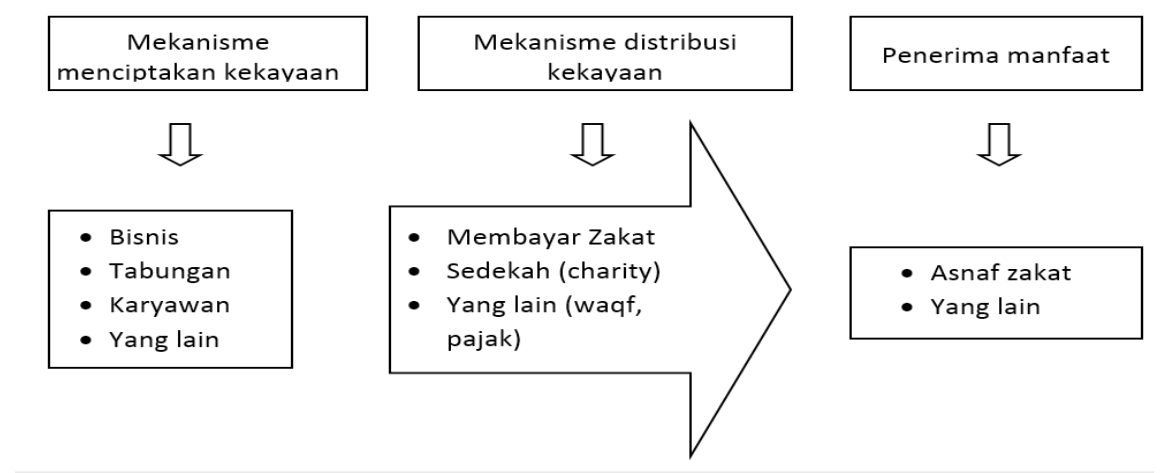

\section{Gambar 1 \\ Mekanisme untuk Mencapai Keadilan Sosial-Ekonomi}

Dengan demikian, zakat dalam perekonomian memiliki fungsi alokatif dan stabilisator. Fungsi alokatif diekspresikan bahwa zakat adalah alat atau instrumen untuk memerangi kemiskinan. Dengan fungsi ini, maka zakat harus diberikan kepada mustahik bukan hanya berupa barang konsumsi tetapi harus berupa barang produksi. Ini dapat dilakukan ketika mustahik memiliki kapasitas dan kemampuan untuk mengolah dan mengelola dana zakat melalui aktivitas ekonomi produktif.

Fungsi zakat secara ekonomi dapat terlihat dalam beberapa hal, yaitu : transper pendapatan dan kekayaan, pengembangan sumber daya mustahik zakat, pemenuhan kebutuhan konsumsi mustahik, dan pengembangan ekonomi produktif mustahik (Fauzia, 2013: 278-282).

Secara sosial zakat merupakan sebuah konsep intervensi sosial berbasis agama untuk mencapai kesejahteraan sosial. Zakat sebagai sebuah sistem tentunya menyediakan jaminan sosial bagi umat Islam terutama bagi fakir dan miskin. 
Secara umum Syahatah (2007:81-82) menyebutkan fungsi sosial zakat adalah untuk menyelamatkan kehidupan manusia baik dalam konteks individu maupun kemasyarakat. Fungsi sosial zakat dapat dirinci sebagai berikut : a) Zakat berfungsi sebagai sarana jaminan sosial dan sarana pemersatu masyarakat dalam memenuhi kebutuhan-kebutuhan pokok setiap individu, memberantas kemiskinan dan penyia-nyiaan terhadap sesama kaum muslim; b) Sebagai pelunak hati dan alat penyebaran dan penyiaran Islam, c) Untuk membebaskan sesama manusia dari perbudakan dan penghambaan, serta mengembalikannya pada kemuliaan dan kemerdekaannnya sebagai anak adam hamba Allah SWT, d) Sebagai sarana untuk memperbesar volume harta yang disediakan sebagai jamianan sosial dalam permasalahan utang-piutang dan payung sosial untuk melindungi kaum miskin ketika mereka punya utang, e) Sebagai salah satu sumber keuangan untuk menutupi kebutuhan musafir yang kehabisan bekal selama diperjalanan,

\section{Keuangan Mikro Islam dalam Pemberdayaan Zakat}

Keuangan mikro Islam sangat berpotensi secara signifikan untuk mengurangi kemiskinan karena keuangan mikro merupakan alat penting dalam meningkatkan produktivitas masyarakat miskin dan membantu dalam pembangunan ekonomi. El Komi (2013:252269) kemudian melakukan uji coba produk pembiayaan keuangan mikro Islam dengan menggunakan skema profit and loss sharing dalam konteks asimetrik informasi. Ternyata kepatuhan dalam kontrak profit and loss sharing secara signifikian lebih tinggi dibandingkan dengan kontrak berbasis interes (bunga). Disamping itu kepatuhan wanita lebih tinggi dibandingkan dengan laki-laki. Pada umumnya tingkat kepatuhan ini dipengaruhi oleh religiusitas individu yang melakukan kontrak.

Model perpaduan antara lembaga keuangan mikro dengan zakat dapat digunakan sebagai pendekatan alternatif dalam mengurangi kemiskinan. Menurut mereka lembaga keuangan 
mikro Islam yang berbasis amal akan berkelanjutan secara finansial dan sosial berdasarkan konsep persaudaraan, filantropi lokal (desentralisasi), dan layanan sukarelawan (pertanggungjawaban bersama). Sehingga lembaga keuangan mikro Islam berbasis zakat ini akan menyediakan dan mengeksplorasi uang untuk konsumsi serta tujuan produktivitas, oleh karena itu, dapat secara luas menargetkan kebutuhan ekonomi dan sosial bagi masyarakat miskin (Possumah dan Ismail, 2011).

Pemberdayaan zakat yang dilakukan melalui mekanisme keuangan mikro Islam dalam mengelola dana zakat, infak dan sedekah didistribusikan dalam bentuk pembiayaan modal usaha kepada penerima manfaat yang kurang mampu secara ekonomi dan harus disertai dengan kegiatan lain seperti pemberian pelatihan, pembinaan, dan pendampingan untuk memberikan power dalam bentuk kemampuan kewirausahaan sehingga dana yang disalurkan tersebut benar-benar produktif dan memberikan efek yang berkelanjutan bagi kehidupan penerima manfaat zakat (Suryanto dan Saepulloh, 2016: 1-27). Di samping itu perlu dilakukan pengawasan dengan tujuan untuk evaluasi sehingga terjadi perbaikan berkelanjutan, efektivitas pemberdayaan zakat, baik dari sisi waktu, material dan tenaga. Pengawasan juga berguna untuk membantu menegakkan peraturan agar ditaati, sehingga dapat dicapai efisiensi yang optimal (Bahjatulloh, 2016: 473-494).

Dengan demikian perpaduan antara lembaga keuangan mikro Islam dengan zakat ditujukan untuk memberi modal kepada orang fakir dan miskin untuk membangun bisnis mereka sendiri, dan juga memberi mereka insentif untuk bekerja dengan tekun untuk mengembalikan jumlah pokok, tanpa harus membayar biaya tambahan.

\section{Karaketristik Pembiayaan Keuangan Mikro Islam}

Ada beberapa karakteristik pembiayaan keuangan mikro Islam yang dapat dijadikan sebagai tolok ukur esensi keuangan mikro 
Islam, diantaranya adalah : 1) Prinsip syariah dalam jasa lembaga keuangan dengan kriteria : halal dalam zat dan sifat dan proses atau cara, anti maysir (perjudian), anti gharar (manipulasi), anti riba (bunga) ( Suryanto, 2005; 2017: 47-58). 2) Akses pembiayaan yang diberikan kepada orang miskin adalah bebas bunga. Hal ini dapat terealisasi jika sistem keuangan mikro Islam terintegrasi dengan lembaga zakat dan wakaf (Laila, 2010). 3) Keuangan mikro Islam mengacu pada penyediaan akses pinjaman kecil tanpa anggunan fisik. Sehingga mendorong orang miskin untuk menyimpan secara teratur dan mengkombinasikan penghematan dan swadaya untuk pengembangan mereka sendiri (Laila, 2010). 4) Keuangan mikro Islam dapat memaksimalkan pelayanan sosial dengan menggunakan dana zakat dan wakaf sebagai sumber dana untuk pembiayaan dalam memenuhi kebutuhan dasar dan meningkatkan partisipasi masyarakat miskin (Rahim, Rahman, 2007: 38-53). Karena zakat dan sedekah merupakan instrumen amal yang menempati posisi sentral dalam skema Islam untuk pengentasan kemiskinan (Laila, 2010). 5) Keuangan mikro Islam harus melibatkan tidak hanya kredit melalui pembiayaan utang non komersial seperti qardul hasan, transfer uang seperti zakat dan sadaqah, serta asuransi melalui konsep takaful. Tetapi juga menyediakan pembiayaan ekuitas skema lain untuk usaha komersial seperti murabahah, mudarabah dan musharakah, skema tabungan wadiah dan mudarabah melalui deposito (Abdul Rahim Abdul Rahman, 2010: 284-295). 6) Mekanisme pembiayaan keuangan mikro dapat disebarkan dengan menggunakan basis kelompok pinjaman. Ini sebagai cara yang paling layak, efektif dan efisien untuk memberikan pembiayaan kepada orang miskin (Dusuki, 2006: 2; Tantoro, 2014: 50).

\section{Pinjaman Modal Berbasis Kelompok}

Bagi kelompok masyarakat miskin produktif tetapi mereka tidak memiliki jaminan untuk akses permodalan pada keuangan Islam, maka jaminan keamanan pembiayaan dapat dilakukan melalui pinjaman berbasis kelompok. 
Pinjaman modal berbasis kelompok-yang merupakan salah satu fitur terpenting dari keberhasilan inisiatif keuangan mikro dengan menggunakan modal sosial-dapat dipergunakan. Konsep ini secara langsung berkaitan dengan solidaritas sosial. Modal sosial dapat mengembangkan nilai positif seperti rasa memiliki, kerjasama tim, dan yang lebih penting adalah kepercayaan. Nilai-nilai semacam ini tentunya lahir didasarkan pada paradigma religius yang mungkin sangat berperan sebagai sumber keberhasilan pekerjaan dalam mekanisme pemberian pinjaman berbasis kelompok (Asyraf Wajdi Dusuki, 2006).

Dalam hal ini, modal sosial sangat penting untuk keberhasilan perancangan program pemberian pinjaman berbasis kelompok dalam meningkatkan akses pendapatan kaum miskin atau kelompok low income. Modal sosial yang tercermin dalam aktivitas perkumpulan yang kuat diyakini sebagai alat yang efektif untuk mengurangi biaya transaksi dan menurunkan eksposur terhadap berbagai risiko keuangan dalam hubungannya dengan pemberian pinjaman kepada masyarakat miskin. Disamping itu dapat meningkatkan kemampuan peminjam untuk berpartisipasi dalam transaksi kredit yang menyangkut persoalan ketidakpastian mengenai kepatuhan dan sejumlah hambatan finansial.

Modal sosial memainkan peran kunci yang memungkinkan rumah tangga memanfaatkan sumber daya manusia yang tersedia dalam bentuk praktik dan pengembangan pengetahuan baru tentang teknologi, menghasilkan modal ekonomi dan sumber daya manusia serta membuat proses pembangunan berkelanjutan (Abul Hassan, 2014:76-90).

\section{Metode Penelitian}

Penelitian ini merupakan penelitian kualitatif dengan menggunakan metode penelitian grouded yakni bergerak dari level empirikal menuju ke level konseptual-teoritikal. (Bungin, 2003; Sugiyono, 2005; Strauss \& Corbin, 2013). Hal ini dilakukan dengan tujuan untuk membangun sebuah teori melalui eksplorasi empirik tentang 
pemberdayaan zakat yang dilakukan microfinance syariah berbasis masyarakat (misykat) DPU DT.

\section{Sumber Data}

Sumber data dalam penelitian ini terdiri dari sumber data primer, yaitu para pengelola microfinance syariah berbasis masyarakat (misykat) DPU DT, pendamping, dan para anggota majelis misykat. Sedangkan sumber data sekundernya adalah berupa dokumen-dokumen kegiatan misykat DPU DT.

\section{Teknik Pengumpulan Data}

Teknik pengumpulan data yang digunakan dalam penelitian ini adalah sebagai berikut : 1) Interview. Teknik interview atau wawancara dilakukan melalui wawancara secara mendalam (deef interview) terhadap pelaksana microfinance syariah berbasis masyarakat (misykat) DPU DT dari mulai pimpinan misykat sampai pada pelaksana teknis. Di samping itu juga, peneliti melakukan wawancara kepada anggota misykat secara acak; 2) Observasi. Peneliti melakukan observasi dengan mengamati kegiatan-kegiatan microfinance syariah berbasis masyarakat (misykat) DPU DT.

\section{Teknik Analisis Data}

Analisis data dilakukan secara kualitatif dengan model interaktif melalui tahapan analisis sebagai berikut : 1) Pada tahap describing, peneliti melakukan penjelajahan pengumpulan data secara umum dalam berbagai segi mengenai pemberdayaan zakat yang dilakukan DPU DT melalui kegiatan microfinance syariah berbasis masyarakat (misykat); 2) Tahap classifying atau categorizing, pada tahap ini peneliti melakukan deskripsi data berdasarkan klasifikasi data dengan memperhatikan konsep-konsep dan gejala-gejala yang terjadi dalam pemberdayaan zakat pada microfinance syariah berbasis masyarakat (misykat) DPU DT; 3) Tahap terakhir analisis 
data, yakni tahap connecting peneliti melakukan konstruksi dengan cara menghubungkan kategori-kategori yang berhubungan dengan pemberdayaan zakat pada microfinance syariah berbasis masyarakat (misykat) DPU DT sehingga dapat dibuatkan deskripsi secara lengkap yang pada akhirnya dapat diambil sebuah kesimpulan.

\section{Hasil dan Pembahasan}

Microfinance Syariab Berbasis Masyarakat (misykat) DPU Daarut Taubiid

Program microfinance syariah berbasis masyarakat (misykat) DPU DT lahir sebagai jawaban atas kondisi ekonomi masyarakat yakni kemiskinan, keterlibatan masyarakat dari praktek rentenir. Untuk keluar dari kondisi tersebut, maka masyarakat membutuhkan pembinaan, edukasi yang berkesinambungan. Proses pemberdayaan yang dilakukan oleh microfinance syariah berbasis masyarakat (misykat) DPU DT tidak hanya memberikan pembiayaan modal kepada anggota majelis tetapi juga melakukan pendampingan dan pembinaan dalam bentuk edukasi pendidikan pola pikir dan karakter, termasuk sharing dalam pengembangan usaha anggota majelis. Seperti belajar membaca al Qur'an, belajar tauhid, akhlak, motivasi usaha, pelatihan program-program usaha seperti kuliner, pengemasan, maintenance produk dan sebagainya. Dengan proses pembelajaran tersebut membuka wawasan anggota majelis misykat baik dalam hal pengetahuan dan pemahaman keagamaan maupun wawasan berwirausaha sehingga terjadi perubahan sikap dan perilaku ke arah yang lebih baik. Hal ini dilakukan melalui proses pendampingan yang mengacu pada konsep tata nilai yang disebut dengan Manajemen Qolbu (MQ) yang diiniasi oleh AA Gym selaku founding father Pondok Pesantren Daarut Tauhiid, dimana konsepsi dasar MQ meliputi 4 komponen, yaitu: ma'rifatullah, manajemen diri, entrepreneurship, dan leadership sebagai upaya untuk pengembangan sumber daya insani yang dilakukan oleh Daarut Tauhiid. 


\section{Kelompok Peminjam}

Kelompok peminjam pada program microfinance syariah berbasis masyarakat (misykat) DPU Daarut Tauhiid biasa disebut dengan majelis misykat yang sekaligus merupakan sebuah kelompok binaan misykat DPU Daarut Tauhiid dalam pemberdayaan zakat. Mereka adalah terdiri dari ibu-ibu yang berusia produktif dari golongan ekonomi menengah ke bawah. Kelompok-kelompok peminjam ini lahir dari inisiatif ibu-ibu sendiri untuk memberdayakan dan mengembangkan potensi produktivitas mereka yang berada di lingkunganya, terutama yang sudah memiliki usaha tetapi masih memerlukan modal untuk pengembangan dan mempertahankan usahanya. Seperti pengalaman Ibu Nur Halimah yang merupakan pendiri majelis misykat al Hikmah di Tasikmalaya, berkat kegigihan dan kerja kerasnya bedirilah misykat al Hikmah. Pada awalnya beliau mengajak ibu-ibu yang berada di lingkungan masjid Al-hikmah dan sekitar tempat tinggalnya, dengan mendatanginya secara door to door untuk mengajak bergabung dalam sebuah kelompok ibu-ibu produktif. Dengan perlahan tapi pasti Ibu Nur Halimah mengajak berbicara ibu-ibu tetangganya dari hati ke hati dengan memaparkan program kelompok produktif yang akan di jalankanya jika mereka mau bergabung. Setelah terbentuk kelompok ibu-ibu produktif, mereka kemudian meminta persetujuan pemerintah setempat yakni pihak RT dan RW mengenai program yang akan di jalankanya. Proses terakhir adalah ibu Nur mendatangi kantor DPU Daarut Tauhiid Priangan Timur yang terletak di Jl. Ir. H. Juanda, untuk melaporkan dan mendaftarkan majelisnya untuk menjadi bagian dari program misykat di bawah binaan DPU Daarut Tauhiid. Maka diresmikanlah kelompok ibu-ibu produktif tersebut dengan mununjuk Ibu Nur Halimah sebagai ketua Majelis Misykat al Hikmah.

\section{Pembiayaan Modal Usaha}

Pemberdayaan dana zakat pada program microfinance syariah berbasis masyarakat (misykat) DPU Daarut Tauhiid dilakukan dengan memberikan pembiayaan modal usaha kepada 
penerima manfaat perorangan yang sudah tergabung dalam sebuah kelompok yang disebut majelis misykat. Zakat berbasis institusi keuangan mikro Islam dapat berbentuk pemberian modal kepada orang fakir dan miskin untuk membangun kewirausahaan mereka, serta memberikan insentif kerja bagi mereka dengan mengembalikan jumlah pokok modal, tanpa harus membayar biaya tambahan.

Pembiayaan mikro diberikan secara bertingkat dan bertahap kepada anggota majelis misykat mulai dari besaran Rp. 300.000,-, Rp. 500.000,-, Rp. 1.000.000,-, 1.500.000,- Rp. 2.000.000,-, dan paling tinggi Rp. 3.500.000,-. Dana tersebut disalurkan kepada anggota majelis misykat tanpa jaminan dan harus dikembalikan pokok dana pembiayaannya dalam jangka waktu 40 minggu. Pada tahap awal semua anggota majelis misykat yang mengajukan pembiayaan mulai dengan pembiayaan sebesar Rp.300.000,- jika cicilan pengembalian pokok dalam jangka waktu 40 minggu lancar maka pembiayaan ditingkatkan ke jenjang besaran Rp. 500.000,- begitu seterusnya sampai pada jumlah maksimal pembiayaan sebesar Rp. 3.500.000,-.

Sebelum diberi pembiayaan modal usaha untuk pertama kalinya, para anggota majelis misykat diwajibkan untuk mengikuti pendampingan selama $4-8$ kali pertemuan dengan tujuan agar modal usaha tersebut tidak disalahgunakan. Hal ini sebagai upaya untuk memberikan pemahaman kepada para anggota majelis misykat tentang tujuan pembiayaan yang diberikan dari manajemen Misykat. Jika tahap ini mereka bisa melewatinya, maka para anggota majelis diperkenankan untuk mengajukan proses pembiayaan modal usaha, dan diwajibkan untuk melaporkan aktivitasnya tersebut.

\section{Bentuk Skema Pembiayaan}

Bentuk pembiayaan yang dilakukan oleh misykat DPU Daarut Tauhiid tidak terlepas dari prinsip-prinsip syariah. Skema pembiayaan untuk institusi sosial seperti lembaga zakat dapat menggunakan skema qardhul hasan, dan untuk keberlajutan pembiayaan jika para anggota sudah dapat mandiri dapat dilanjutkan dengan menggunakan skema pembiayaan mudharabah. Dengan 
menggunakan skema pembiayaan yang kedua, maka para anggota majelis sudah memberikan kontribusi kepada lembaga zakat berupa bagi hasil usaha yang akan bermanfaat juga bagi anggota majelis yang lain.

Adapun skema pembiayaan yang dilakukan oleh DPU Daarut Tauhiid dalam program misykat untuk anggota majelis misykat adalah sebagai berikut :

\section{Skema QH (Qardul Hasan)}

Skema pembiayaan yang diberikan kepada anggota majelis misykat dalam bentuk pinjaman lunak tanpa ada pengembalian imbalan atau bagi hasil. Oleh karena itu, yang dikembalikan adalah hanya pokok pinjaman saja. Adapun plafon pembiayaan setiap anggota majelis misykat untuk skema ini maksimal Rp. 1.000.000,00 yang diberikan secara bertahap dan berkesinambungan berdasarkan kebutuhan modal usaha yang diajukan anggota kepada pihak manajemen program.

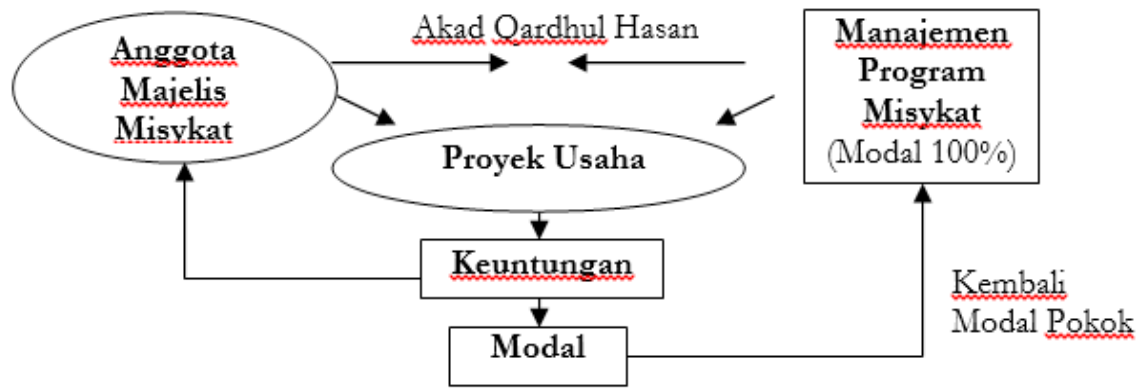

\section{Gambar 2}

Skema Pembiayaan Qardhul Hasan

\section{Skema Mudharabah Muqayyadah}

Skema mudharabah muqayyadah ini merupakan bentuk pembiayaan dengan sistem bagi hasil berdasarkan nisbah keuntungan yang diperoleh anggota. Karakteristik skema ini : (a) manajemen program misykat memberikan batasan atas pembiayaan yang dilakukan. Misalnya hanya untuk jenis usaha tertentu saja, waktu 
tertentu, tempat tertentu dan lain-lain; (b) anggota majelis misykat terikat dengan ketentuan-ketentuan yang telah ditetapkan oleh manajemen program misykat sehingga hanya bisa mengelola dana tersebut sesuai dengan batasan yang diberikan oleh manajemen program misykat.

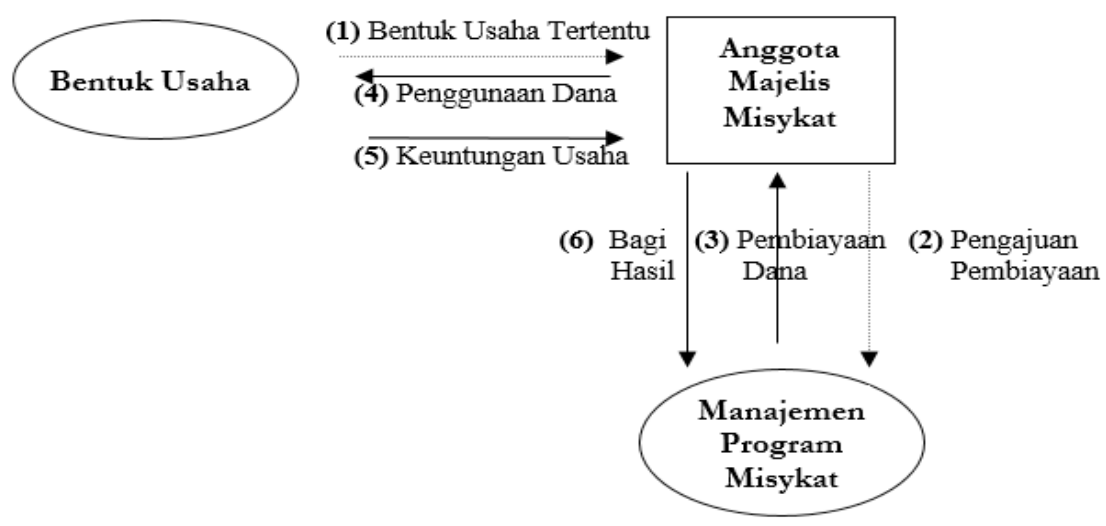

\section{Gambar 3}

\section{Skema Mudharabah Muqayyadah}

Skema pembiayaan mudharabah muqayyadah ini diberikan kepada anggota majelis misykat dengan besaran pembiayaan di atas 1 juta rupiah dengan nisbah bagi hasil ekwivalen dengan margin $15 \%$.

Dalam pemberian pembiayaan pihak manajemen program misykat tetap melakukan serangkaian analisis kelayakan penerima program melalui pemenuhan kriteria sasaran penerima manfaat program dan persyaratan keanggotaan sebagai berikut, yaitu :

1. Kriteria umum yang meliputi : a) lingkup usaha kecil dan terbatas tetapi mampu memobilisasi banyak tenaga kerja kaum mustahik; b) lemah dalam akses permodalan; c) lemah dalam sumber daya insani dan kemampuan manajemen; dan d) lemah dalam akses pemasaran.

2. Persyaratan menjadi anggota misykat yang meliputi : a) mengisi form seleksi yang telah disediakan oleh lembaga; b) penduduk asli dari daerah sesuai dengan program yang digulirkan; c) 
berasal dari keluarga pra sejahtera; d) berkelompok dimana anggota kelompok saling mempercayai dan tidak ada ikatan keluarga, dan rumah mereka berdekatan; d) bersedia mengikuti pengajian setiap seminggu sekali; e) bersedia mengikuti aturan misykat; f) bersedia untuk berwirausaha sesuai dengan minat, kemampuan dan kondisi yang ada; serta g) bersedia menerima keputusan misykat mengenai diterima atau ditolak tentang pengajuan pembiayaan.

Alur pembiayaan yang dilakukan oleh microfinance syariah berbasis masyarakat (misykat) DPU Daarut Tauhiid dapat dilihat pada gambar berikut :

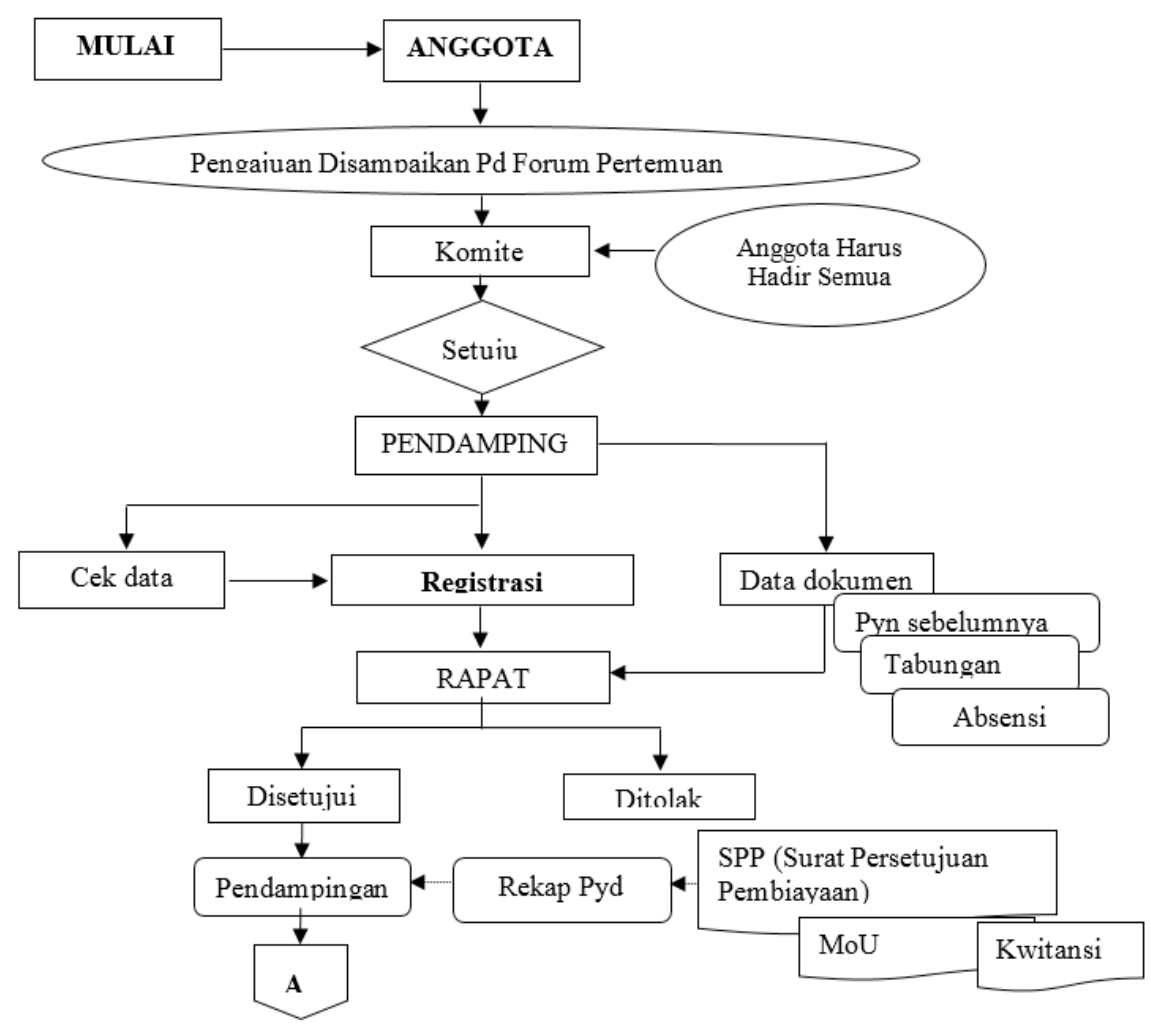

Gambar 4

Alur Pembiayaan Microfinance Syariah Berbasis Masyarakat 


\section{Pendampingan Majelis Misykat}

Pendampingan majelis misykat dilakukan oleh seorang pendamping tetap yang dibantu oleh pendamping mahasiswa yang merupakan penerima beasiswa DPU Daarut Tauhiid. Pendampingan terhadap majelis misykat yang dilakukan sepekan sekali ini merupakan salah satu dari bentuk pelayanan program misykat dalam pemberdayaan zakat melalui program microfinance syariah berbasis masyarakat (misykat) DPU Daarut Tauhiid.

Pendampingan microfinance syariah berbasis masyarakat (misykat) DPU Daarut Tauhiid menggunakan beberapa cara, yaitu 1) pendampingan berbasis pengembangan pengetahuan, 2) pendampingan berbasis penanaman nilai, 3) pendampingan berbasis pengembangan keterampilan. Fungsi pendamping majelis misykat, disamping memberikan wawasan pengetahuan, penanaman nilai-nilai keislaman dalam kehidupan sehari-hari, dan sharing pengembangan keterampilan anggota majelis misykat, pendamping juga berfungsi menjadi pengawas pasca pembiayaan sekaligus sebagai kolektor untuk pelayanan keuangan, diantaranya seperti iuran kelompok, tabungan berencana, cicilan pokok pinjaman, dan bagi hasil usaha.

\section{Kesimpulan}

Pemberdayaan zakat yang dilakukan oleh DPU Daarut Tauhiid adalah mengambil bentuk microfinance syariah berbasis masyarakat (misykat), yaitu pemberdayaan dana zakat dilakukan melalui pemberian pembiayaan mikro untuk modal usaha kepada para mustahik dengan berbasis kelompok dan menggunakan model keuangan mikro Islam yang dilengkapi dengan kegiatan pendampingan yang berfungsi untuk pengawasan pasca pembiayaan, dakwah penanaman nilai-nilai keislaman, dan kolektor. Skema pembiayaan yang digunakan untuk tahap awal adalah qardhul hasan, sedangkan untuk keberlajutan pembiayaan jika para anggota sudah dapat mandiri menggunakan skema pembiayaan mudharabah. 


\section{Daftar Pustaka}

Ahmad, Ausaf. 1984. "A Macro Model of Distribution in An Islamic Economy”. J. Res. Islamic Econ., Vol. 2, No. 1 : 3-18.

Ahmad, Raja Adzrin Raja, at.all. 2015. "Assessing the Satisfaction Level of Zakat Recipients Towards Zakat Management". Procedia Economics and Finance 31 : 140 - 151, Published by Elsevier.

Bahjatulloh, Qi Mangku. 2016. "Pengembangan Pemberdayaan Ekonomi Masyarakat Melalui Kegiatan Filantropi (Studi Kasus Lembaga Tazakka D III Perbankan Syariah IAIN Salatiga)". INFERENSI, Jurnal Penelitian Sosial Keagamaan, Vol. 10, No. $2: 473-494$.

Bakar, Nur Barizah Abu. 2007. "A Comparative Study of Zakah and Modern Taxation". J.KAU: Islamic Econ, Vol. 20, No. 1: 25-40.

Beik, Irfan Syauqi. "Zakat dan Komite Nasional Ekonomi Syariah", dalam www.pusat.baznas.go.id.

Dusuki, Asyraf Wajdi. 2006. "Empowering Islamic Microfinance: Lesson from Group-Based Lending Scheme and Ibn Khaldun's Concept of "Asabiyah", presented at Monash University 4th International Islamic Banking and Finance Conference. Kuala Lumpu, on 13- 14 November 2016.

El-Komi, Mohamed dan Rachel Croson. 2013. "Experiments in Islamic microfinance". Journal of Economic Behavior \& Organization Published by Elsevier B.V.: 252- 269.

Fauzia, Amelia. 2013. "Faith and the State: A History of Islamic Philanthropy in Indonesia". Leiden and Boston, : Brill : 278282.

Gupta, Avnesh Kumar. 2012. "Microfinance and Strategy of Financial Inclusion in India". Journal of Economics and Sustainable Development, Vol.3, No.10.

Hamka, dkk. 2013. Zakat Community Development : Model Pengembangan Zakat. Jakarta : Direktorat Pemberdayaan Zakat Kemenag RI.

Hassan, Abul. 2013. "The challenge in poverty alleviation: role of Islamic microfinance and social capital". Humanomics, Vol. 
30 No. 1 : 76-90. Emerald Group Publishing Limited. DOI 10.1108

Hendri, Nedi dan Suyanto. 2015. "Analisis Model-Model Pendayagunaan Dana Zakat Dalam Pemberdayaan Masyarakat Miskin Kota di Provinsi Lampung", Jurnal Akuisisi Vol. 11 No. $2: 63-73$

Ismail , Abdul Ghafar dan Bayu Taufiq Possumah. 2013. "Theoretical Model for Zakat-Based Islamic Microfinance Institutions in Reducing Poverty", International Research Journal of Finance and Economics. 136-150

Khairi, Nur Zehan, Abd Halim Mohd Noor, and Nor Azizah Mohammad Amin. 2015. "Integrating Zakat Institutions into the Mainstream Economy: Evidence from Malaysia". Islamic perspectives relating to business, arts, culture and communication, Singapore : Springer : 315-323.

Kholiq, Abdul. 2012. "Pendayagunaan Zakat, Infaq dan Sedekah Untuk Pemberdayaan Ekonomi Masyarakat Miskin di Kota Semarang". Riptek Vol. 6, No. 1 : 39 - 47.

Laila, Tanim. 2010. "Islamic Microfinance for Alleviating Poverty and Sustaining Peace". Canakkale Turkey : World Universities Congress.

Oran, Ahmad F. 2009. "Zakat Funds and Wealth Creation", Review of Islamic Economics, Vol. 13, No. 1 : 143-153

Possumah, Bayu Taufiq dan Abdul Ghafar Ismail. 2011. The Quran and Poverty Alleviation: A Theoretical Model for Zakat-Based Islamic Microfinance Institutions, Working Paper in Islamic Economics and Finance No. 1101, Research Center for Islamic Economics and Finance, Selangor, Malaysia : Universitas Kebangsaan Malaysia Bangi.

Qardawi, Yusuf. 2007. Hukum Zakat ; Studi Komparatif mengenai Satus dan Filsafat Zakat Berdasarkan Qur'an dan Hadits. Terj. Salman Harun, Didin Hafidhuddin, Hasanuddin, Judul asli : Fiqhu az Zakah. Bogor : Pustaka Litera AntarNusa.

Rahman, Abdul Rahim Abdul. 2007. "Islamic Microfinance: A Missing Component in Islamic Banking", Kyoto Bulletin of Islamic Area Studies. Vol. 1, No. $2: 38-53$ 
Rahman, Abdul Rahim Abdul. 2010. "Islamic Microfinance : an Ethical Alternative to Poverty Alleviation", Humanomics. Vol. 26, No. 4 : 284-295.

Ramadhita. 2013. "Optimalisasi Peran Lembaga Amil Zakat dalam Kehidupan Sosial", Jurnal Hukum dan Syariah, Vol. 3, No. $1: 24-34$.

Suprayitno, Eko, at.all. 2017. "Zakat and SDGs: Impact Zakat on Human Development in the Five States of Malaysia". International Journal of Zakat Vol. 2, No. 1 : 61-69.

Suryanto, A., 2017. "The Strategy of Realizing Sharia Based School Cooperative in Tasikmalaya City, Indonesia". International Journal of Nusantara Islam, 5(1), pp.47-58.

Suryanto, A., 2005. Fungsi Bank Syariah Dalam Meningkatkan Minat Masyarakat Untuk Menyimpan Dana Dan Mendapatkan Pembiayaan Di Bank Syariah Mandiri Cabang Tasikmalaya Tahun 2005. Universitas Islam Negeri Sunan Gunung Djati Bandung.

Suryanto, A. and Saepulloh, A., 2016. Optimalisasi Fungsi dan Potensi Masjid: Model Pemberdayaan Ekonomi Masyarakat Berbasis Masjid di Kota Tasikmalaya. Iqtishoduna: Jurnal Ekonomi Islam, 5(2), pp.1-27.

Syahatah, Syauqi Ismail. 2007. Penerapan Zakat dalam Bisnis Modern. Terj. Bahrun Abu Bakar dan Anshori Umar Sitanggal, Judul asli : At Tathbiq al Mu'ashir li az Zakah. Bandung : Pustaka Setia.

Tantoro, Swis. 2014. Pembasmian Kemiskinan perspektif Sosiologi Antropologi. Yogyakarta : Pustaka Pelajar.

Tim Penyusun Direktorat Pemberdayan Zakat. 2013. Membangun Perspektif Pengelolaan Zakat Nasional. Jakarta : CV. Sejahtera Kita.

Wahab, Norazlina Abd. dan Abdul Rahim Abdul Rahman. 2011. "A framework to analyse the efficiency and governance of zakat institutions". Journal of Islamic Accounting and Business Research, Vol. 2 No. 1 : 43-62, Emerald Group Publishing Limited. 